\title{
PENGEMBANGAN DAN EVALUASI SISTEM INFORMASI DI INSTALASI GIZI RSJ PROF DR SOEROJO MAGELANG
}

\author{
Basuki Wibowo'), Kusworo Adi $^{\text {2) }}$, Eko Sediono ${ }^{3)}$ \\ 1)2)3) Fakultas Kesehatan Masyarakat, Universitas Diponegoro \\ Jl. Prof. Soedarto No.1269, Tembalang, Kec. Tembalang, Kota Semarang, Jawa Tengah 50275 \\ Email:bas_wibowo@yahoo.co.id
}

\begin{abstract}
Nutrition installation is one of the important supporting service units in a hospital. In the Nutrition Installation of RSJ Prof. Dr. Soerojo Magelang, there are obstacles in the process of planning and supplying food needs including menu planning, cooking and food calculation, where it still performed manually. This study aims to develop and analyze information systems planning and procurement of food needs in the nutritional installation of Prof. Dr. Soerojo Magelang. Qualitative analysis to identify problems is done through in-depth interviews with 3 Nutrition Installation coordinators. System development is carried out with the FAST stages. System operational testing is done by the Black Box method. The research subjects included all nutritionists in RSJ nutrition installations. Research variables include time as an indicator of speed, accuracy as accuracy and relevance as dynamic data. Evaluate and analyze data by evaluating using a questionnaire and comparing the weighted average results of the information system before and after the development of the system.The results of data analysis showed an increase in the quality of information. An increase in speed, accuracy, relevance of 28.0\%, 25.0\%, $21.3 \%$ respectively. Overall there was an increase in the quality of the information system by $24.7 \%$. It can be concluded that with the development of the system, there has been an increase in the process of planning and supplying food needs more quickly, precisely and dynamically.
\end{abstract}

Keywords: Information Systems, Nutrition Installation, planning, procurement, foodstuffs

\begin{abstract}
Abstrak
Instalasi gizi merupakan salah satu unit pelayanan penunjang yang penting dalam sebuah rumah sakit. Di Instalasi Gizi RSJ Prof Dr Soerojo Magelang terdapat kendala dalam proses perencanaan dan pengadaan kebutuhan bahan makanan meliputi perencanaan menu, masakan serta perhitungan bahan makanan yang masih dilakukan secara manual. Penelitian ini bertujuan untuk melakukan pengembangan dan analisa sistem informasi perencanaan dan pengadaan kebutuhan bahan makanan pada instalasi gizi RSJ Prof Dr Soerojo Magelang. Analisa kualitatif untuk mengidentifikasi masalah dilakukan melalui wawancara mendalam kepada 3 koordinator Instalasi Gizi. Pengembangan sistem dilakukan dengan tahapan FAST. Pengujian operasional sistem dilakukan dengan metode Black Box. Subjek penelitian meliputi seluruh ahli gizi yang ada pada instalasi gizi RSJ. Variabel penelitian meliputi waktu sebagai indikator kecepatan, akurasi sebagai ketepatan dan relevansi sebagai data yang dinamis. Evaluasi dan analisis data dengan penilaian menggunakan ceklis serta membandingkan hasil rata - rata tertimbang sistem informasi sebelum dan sesudah adanya pengembangan sistem. Hasil analisis data menunjukkan terjadi peningkatan kualitas informasi. Terjadi peningkatan kecepatan, akurasi, relevansi masing-masing sebesar 28,0\%, 25,0\%,21,3\%. Secara keseluruhan terjadi peningkatan kualitas sistem informasi sebesar $24.7 \%$. Dapat disimpulkan bahwa dengan adanya pengembangan sistem, telah terjadi peningkatan proses perencanaan dan pengadaan kebutuhan bahan makanan secara lebih cepat, tepat dan dinamis.
\end{abstract}

Kata Kunci: Sistem Informasi, Instalasi Gizi, perencanaan, pengadaan, bahan pangan

\section{Pendahuluan}

Penerapan Sistem Informasi Rumah Sakit (SIMRS) telah menjadi kebutuhan dasar dalam menunjang kelancaran berbagai unit pelayanan di rumah sakit, termasuk aplikasinya di instalasi gizi.[1] RSJ. Magelang (RSJS) sebagai rumah sakit tipe A secara umum telah menerapkan SIMRS sejak tahun 2005.
Namun dalam operasionalnya instalasi gizi belum memiliki suatu aplikasi khusus dalam melakukan perencanaan serta perhitungan kebutuhan bahan makanan.[2] Pada kegiatan penyelenggaraan makanan di instalasi gizi terdapat proses perencanaan menu, perencanaan kebutuhan bahan makanan (BM), pengadaan bahan makanan serta penerimaan bahan makanan yang diperlukan dalam menyusun kebutuhan 
pengadaan bahan makanan.[3] Sistem informasi yang ada pada instalasi gizi dilakukan dengan membuat form - form dengan menggunakan aplikasi Microsoft Excel dan pengolahan data secara manual. Pengembangan sistem informasi gizi di rumah sakit diperlukan dalam mengoptimalkan perawatan nutrisi pada pasien.[4] Dalam keseharian, sistem informasi yang ada pada instalasi gizi RSJS dirasa belum berjalan secara optimal.

Adapun kendala dan keterbatasan sistem informasi yang ada sekarang, diantaranya : Adanya keterbatasan dalam integrasi data jumlah pasien antara sistem informasi instalasi gizi dengan Sistem Informasi Rumah Sakit (SIRS). Proses perencanaan menu dan perhitungan kebutuhan bahan makanan berdasarkan hari, kelas, waktu penyajian, jenis masakan, jenis bahan makanan yang cukup banyak dan bervariatif sehingga membutuhkan tenaga serta waktu pengolahan yang lama. Penegakan standarisasi diperlukan untuk mengurangi subyektifitas petugas dalam menentukan menu, masakan serta pemakaian jumlah kebutuhan bahan makanan. Adanya permasalahan tersebut tentu berpengaruh terhadap kualitas informasi yang dihasilkan.[5]

Upaya pengembangan SI diperlukan dalam meningkatkan kualitas informasi meliputi : akurasi (accurate), tepat waktu (timeliness) dan relevan (relevance). Penelitian ini bertujuan melakukan pengembangan SI Perencanaan dan Pengadaan Menu Makanan di Instalasi Gizi RSJS serta melakukan evaluasi sistem sebelum dan sesudah ujicoba adanya pengembangan sistem informasi.

\section{Metodologi Penelitian}

Penelitian ini dilakukan di. RSJ. Prof. Dr. Soerojo Magelang, Jl. Ahmad Yani 169 Magelang, Kabupaten Magelang, Propinsi Jawa Tengah. Jenis penelitian ini menggunkana metode kualitatif dalam proses identifikasi masalah pada setiap tahap pengembangan SI Perencanaan dan Pengadaan Menu Makanan. Metode kuantitatif digunakan dalam mengukur kualitas informasi yang dihasilkan sebelum dan sesudah dilakukan pengembangan. Variabel penelitian dalam pengembangan SI Perencanaan dan Pengadaan Menu Makanan di Instalasi Gizi RSJ. Prof. Dr. Soerojo Magelang adalah aspek kualitas informasi meliputi akurasi, ketepatan waktu dan relevansi.[6]

Pada penelitian pendekatan kualitatif dilakukan dengan melakukan wawancara mendalam (indepth interview) dengan pengguna sistem. Pengguna sistem disini ada 3 orang, meliputi : Kepala Instalasi Gizi RSJ, Koordinator Bagian Perencanaan dan Pengadaan Bahan Makanan Instalasi Gizi RSJS serta Koordinator Produksi Instalasi Gizi RSJ.

Pendekatan kuantitatif digunakan untuk melakukan evaluasi terhadap kualitas informasi meliputi : akurasi, ketepatan waktu, dan relevansi. Evaluasi dilakukan sebelum dilakukan pengembangan SI dan sesudah dilakukan pengembangan SI evaluasi dilakukan dengan melakukan pengisian dengan menggunakan kuesioner dan lembar ceklis.

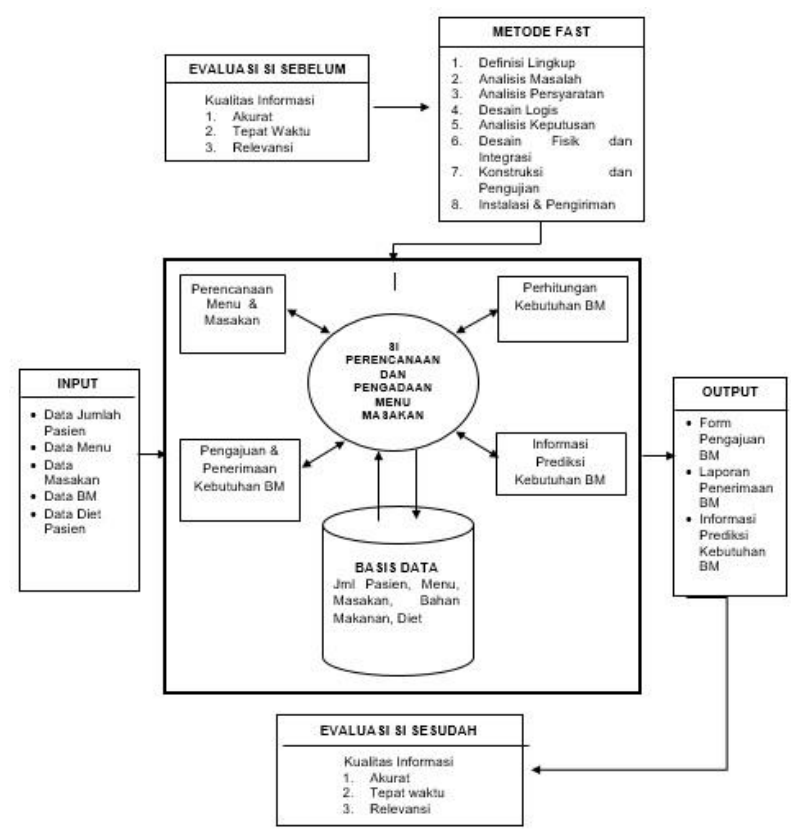

Gambar 1. Kerangka Konsep Penelitian

\section{Instrumen dan cara Penelitian}

a. Instrumen Pengumpulan Data

Instrumen pengumpulan data yang digunakan yaitu dengan melakukan observasi pada sistem informasi yang berjalan sekarang, pedoman wawancara, dan ceklis penilaian kualitas informasi yang dihasilkan sebelum dan sesudah ujicoba pengembangan SI Perencanaan dan Pengadaan Menu Makanan instalasi gizi RSJS.

b. Cara Penelitian

Alur penelitian yang dilakukan pada penelitian ini sesuai dengan tahapan pada metodelogi FAST, meliputi :[7]

1) Definisi Lingkup

Tahapan ini akan dilakukan serangkaian kegiatan untuk mengetahui adanya masalah yang timbul dan peluang pengembangan yang ada dari sistem sekarang. Melakukan observasi dan wawancara langsung dari pengguna sistem dalam mendapatkan gambaran pengembangan SI. Hal tersebut akan berkaitan dengan pemakaian SI Perencanaan dan Pengadaan Menu Makanan di Instalasi Gizi RSJS dan meminimalisir masalah yang ada pada sistem yang sedang berjalan sekarang.

2) Analisis Permasalahan

Pada tahapan ini akan dilakukan analisis untuk memperoleh pemahaman yang lebih jelas mengenai alasan pengembangan sistem baru, seperti mempelajari dan menganalisis SI yang berjalan saat ini di instalasi gizi RSJS serta pada sistem yang akan dirancang. 
3) Analisis Kebutuhan

Pada analisis kebutuhan dilakukan serangkaian kegiatan dalam pendefinisian kebutuhan informasi apa saja yang dibutuhkan dalam penyusunan SI. Informasi tersebut diperoleh dari pengguna SI Perencanaan dan Pengadaan Menu Makanan di Instalasi Gizi. Pengguna sistem disini adalah kepala instalasi gizi, koordinator perencanaan dan pengadaan serta koordinator produksi instalasi Gizi.

4) Desain Logis

Berdasarkan analisis kebutuhan sesuai dengan alur bisnis dalam kegiatan perencanaan dan pengadaan kebutuhan bm instalasi gizi, maka kemudian akan dibuat gambaran model sistem berupa struktur data, bisnis proses, alur data, serta desain antar muka (user interface) pengguna sistem.

5) Analisis Keputusan

Menentukan pilihan sistem yang akan dibuat dengan mempertimbangkan berbagai masalah yang ada dengan melihat dari segi ekonomi, sumber daya serta sarana dan prasarana yang ada. Menentukan Database Managemen System (DBMS) serta Bahasa pemprograman yang sesuai dengan SI Instalasi Gizi RSJS.

6) Desain fisik dan integrasi

Merancang SI Perencanaan dan Pengadaan Menu Makanan di instalasi gizi dengan perangkat pemodelan sistem supaya dapat sesuai dengan kebutuhan pengguna dalam meningkatkan kualitas pengolahan data, pencatatan, dan pelaporan. Perancangan tersebut berupa perancangan input, basis data, output, serta perancangan desain antarmuka.

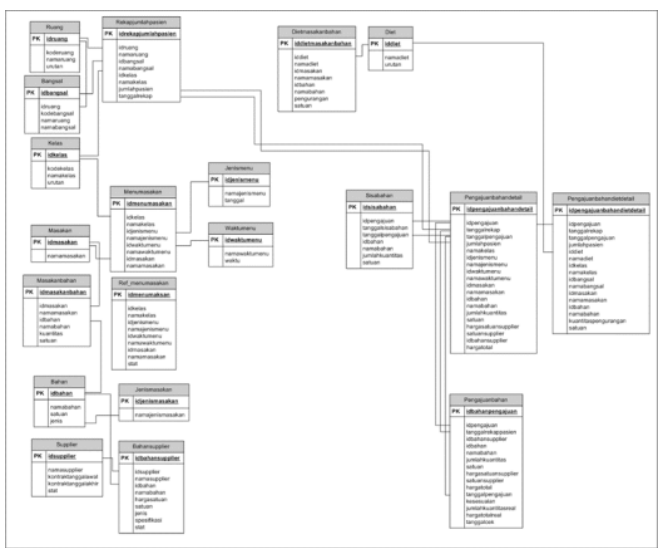

Gambar 2. Tampilan ERD sistem informasi perencanaan menu dan pengadaan bahan makanan

7) Konstruksi

Membangun basis data dan aplikasi dengan menterjemahkan hasil rancangan ke dalam programan komputer. Pemprograman dan manajemen basis data dengan menggunakan PHP MySQL.

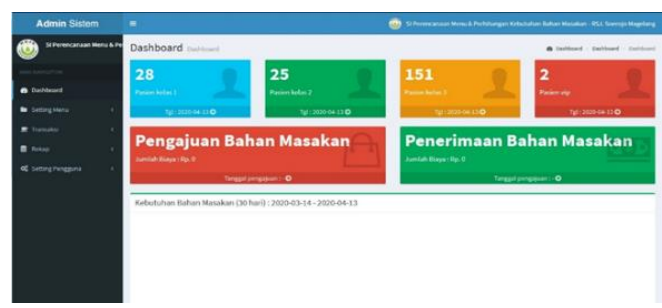

Gambar 3. Tampilan dashboard dan informasi jumlah pasien.

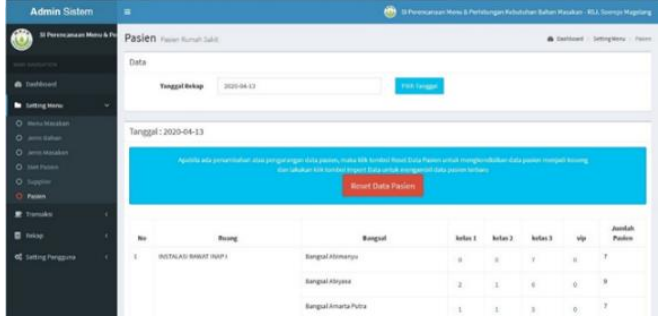

Gambar 4. Tampilan jumlah pasien.

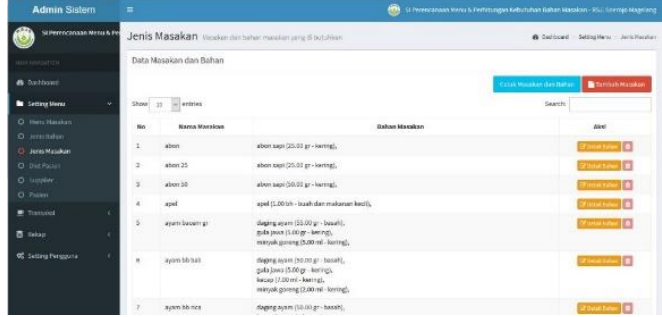

Gambar 5. Tampilan dashboard setting jenis masakan

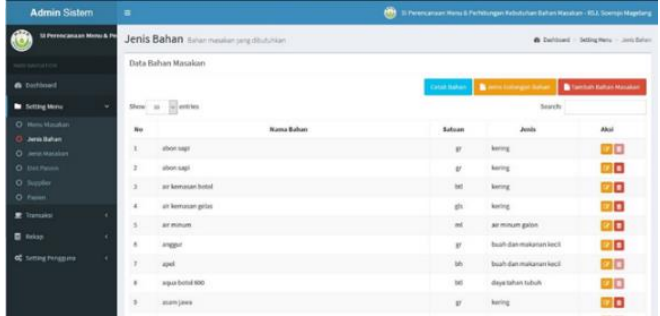

Gambar 6. Tampilan dashboard setting jenis bahan makanan

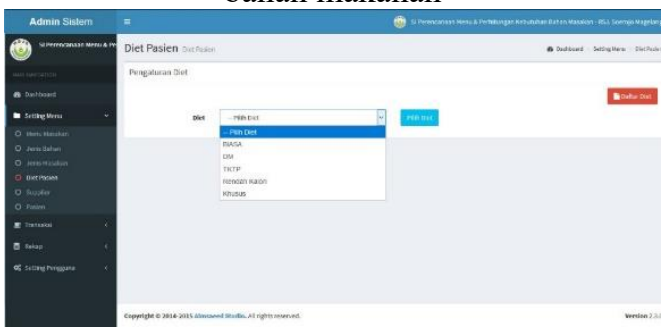

Gambar 7. Tampilan dashboard setting diet

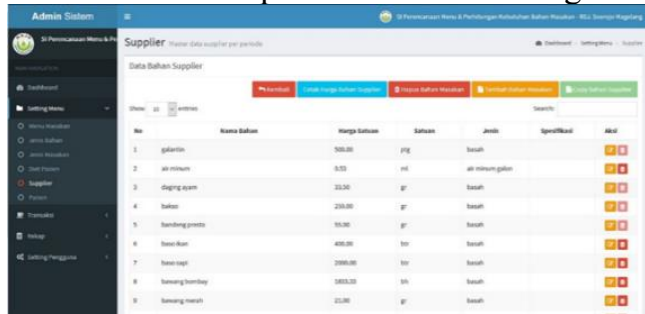

Gambar 8. Tampilan dashboard setting diet 


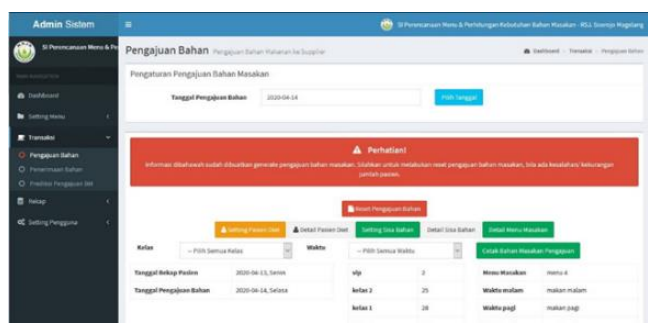

Gambar 9. Tampilan pengajuan kebutuhan bahan makanan

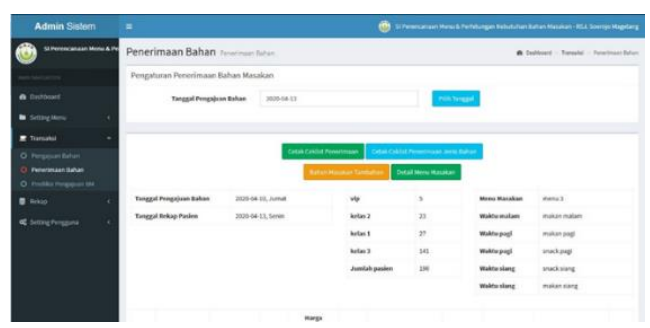

Gambar 10. Tampilan penerimaan kebutuhan bahan makanan

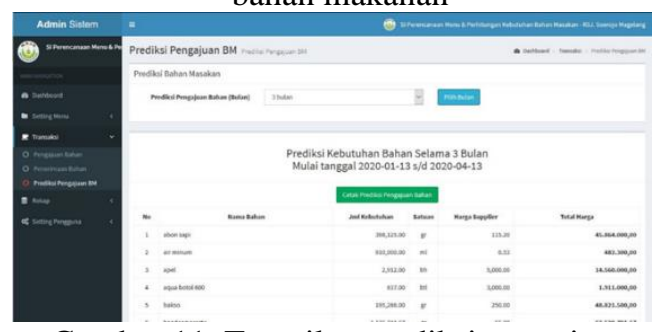

Gambar 11. Tampilan prediksi pengajuan kebutuhan bahan makanan

Pengujian

Pengujian perangkat lunak dilakukan dengan metode blackbox pada 15 tampilan menu sistem oleh dua orang staf IT RSJS. Pengujian dilakukan apakah fungsi, input dan output yang dihasilkan program sudah sesuai dengan spesifikasi yang diperlukan.[8]

8) Instalasi Sistem

Merupakan instalasi sistem yang baru, diperlukan adanya suatu proses transisi dari sistem lama ke sistem yang baru. Operasional sistem akan memerlukan pelatihan pada petugas yang mengoperasikan. Adanya dokumentasi dalam penggunaan sistem juga diperlukan dalam membantu pengguna sistem.

\section{Teknik Pengolahan dan Analisa Data \\ a. Pengolahan Data}

Dimulai dari editing dan koding dengan cara meneliti setiap form pengumpulan data sehingga data yang dikumpulkan lengkap dan jelas. Kemudian data diolah secara manual dengan menghitung rata-rata tertimbang untuk mengetahui perbedaan kualitas data dengan sistem yang ada dengan yang akan dikembangkan.

b. Analisis Data

1) Analisis Isi (content analysis)

Data kualitatif hasil observasi dan wawancara akan dilakukan analisis isi, analisis dalam bentuk naratif secara sistematis dan obyektif. Analisis ini juga diperlukan dalam menemukan permasalahan pada sistem yang berjalan, menemukan kebutuhan pengguna serta menyempurnakan model.

2) Rata - rata tertimbang

Rata-rata tertimbang adalah rata-rata yang dihitung berdasar bobot masing-masing datanya.[9] Analisis hasil evaluasi dari sistem menggunakan rata-rata tertimbang dengan rumus sebagai berikut :

$$
\left\{\frac{\sum_{\text {Responden pada tingkat persetujuan } x \text { bobot pertanyaan }}^{(1,2,3,4,5)}}{\text { Jumlah Responden }}\right\}
$$

Rata-rata Keseluruhan $=\frac{\sum \text { Rata }- \text { rata tertimbang }}{\sum \text { Item } \text { Penilaian }}$

Evaluasi yang dilakukan adalah membandingkan angka rata-rata tertimbang kualitas informasi pada SI yang lama dan juga kualitas informasi pada SI yang sedang dikembangkan.

Pengukuran dilakukan dengan menggunakan skala Likert. Skala ini terdiri dari macam 5 jawaban yaitu sangat setuju (SS), Setuju, (S), Ragu-ragu (RR), Tidak Setuju (TS), Sangat tidak setuju (STS). Bobot jawaban ceklis pengukuran kualitas SI adalah sebagai berikut :[10]

Sangat setuju (SS) $\quad=5$

Setuju (S) $\quad=4$

Ragu-ragu (RR) $\quad=3$

Tidak Setuju (TS) $\quad=2$

Sangat tidak setuju (STS) $\quad=1$

Metode tersebut akan digunakan sebagai materi pre dan post tes sehingga pengguna aplikasi akan diberikan ceklis pertanyaan mengenai kualitas informasi. Ceklis akan diberikan sebelum pengguna aplikasi menggunakan aplikasi dengan mengisi ceklis kualitas informasi sesuai sistem yang berjalan sekarang, kemudian pengguna akan diberikan sistem baru yang setelah itu pengguna aplikasi akan diberikan ceklis kualitas informasi yang sama dan diisi sesuai dengan sistem yang baru. Hasil akan dibandingkan antara sebelum dan sesudah dilakukan pengembangan SI. Evaluasi SI berguna dalam melihat efektivitas suatu sistem.[11]

\section{Hasil}

Proses untuk mengidentifikasi permasalahan dilakukan dengan wawancara mendalam. Dari hasil wawancara ditemukan beberapa permasalahan sedang berlangsung saat ini, yaitu:

a) Proses input jumlah pasien yang terlebih dahulu harus direkap dari komputer rekam medis oleh petugas instalasi gizi. Rekap ini dalam prosesnya dicatat dan dihitung secara manual sehingga cukup menyita waktu serta rentan adanya kesalahan perhitungan.

b) Macam menu, masakan, bahan makanan serta diet yang cukup banyak dan bervariatif.

c) Adanya subyektifitas petugas dalam menentukan jumlah masakan dan bahan makanan dalam proses perencanaan menu dan perhitungan kebutuhan bahan makanan. Ketepatan dalam pemberian jumlah bahan 
makanan turut memberikan asupan diet yang sesuai bagi pasien.

Hasil dan Analisis Penerapan SIMRS

Hasil perhitungan rata-rata tertimbang dari poin kuesioner yang diberikan kepada para responden menunjukkan hsail sebagai berikut:

Tabel 1. Hasil pengujian SI sebelum dan sesudah uji coba

\begin{tabular}{llcccccc}
\hline \multirow{2}{*}{ PERNYATAAN } & \multicolumn{2}{c}{$\begin{array}{c}\text { Rata-rata } \\
\text { Sebelum }\end{array}$} & \multicolumn{2}{c}{$\begin{array}{c}\text { Rata-rata } \\
\text { Sesudah }\end{array}$} & \multicolumn{2}{c}{ Selisih } \\
\cline { 2 - 7 } & & Nilai & $\%$ & Nilai & $\%$ & Nilai & $\%$ \\
\hline A & Akurasi & 3.61 & $72.1 \%$ & 4.86 & $97.1 \%$ & 1.25 & $25.0 \%$ \\
\hline B & Waktu & 3.50 & $70.0 \%$ & 4.90 & $98 \%$ & 1.40 & $28.0 \%$ \\
\hline C & Relevansi & 3.81 & $76.3 \%$ & 4.88 & $97.5 \%$ & 1.06 & $21.3 \%$ \\
\hline & RATA-RATA & $72.8 \%$ & $97.5 \%$ & & $24.7 \%$ \\
\hline
\end{tabular}

Dari tabel 4.48 diatas diketahui bahwa dengan adanya pengembangan SI Perencanaan dan Pengadaan Menu Makanan pada Instalasi gizi RSJS telah terjadi peningkatan kualitas informasi sebesar $24.7 \%$, dari sistem sebelumnya sebesar $72.8 \%$ meningkat menjadi $97.5 \%$.

Peningkatan paling banyak dari sisi waktu sebesar 28.0 $\%$, dari sisi akurasi meningkat sebesar $25.0 \%$ dan dari sisi relevansi terjadi kenaikan sebesar $21.3 \%$.

Hasil evaluasi menunjukkan bahwa secara keseluruhan pengembangan SI Perencanaan dan Pengadaan Menu Makanan dapat menghasilkan kualitas informasi yang lebih baik dibanding dengan sistem sebelumnya.

\section{Pembahasan}

Sistem Informasi Perencanaan dan Pengadaan Kebutuhan Bahan Makanan ini dikembangkan dengan metode pengembangan sistem Framework for The Application of System Thinking (FAST) yang dijabarkan dalam tabel studi kelayakan yang menunjukkan bahwa pengembangan SI Perencanaan dan Pengadaan Menu Makanan di instalasi gizi RSJS ini memang layak untuk dikembangkan. Pengembangan SI Perencanaan dan Pengadaan Menu Makanan memungkinkan petugas instalasi gizi dapat melakukan analisis perhitungan bahan pangan dengan lebih dinamis, efisien dan akurat. Asupan diet yang tidak sesuai dengan kebutuhan dapat membutuhkan waktu perawatan pasien yang lebih lama.[3]

Pengembangan SI Perencanaan dan Pengadaan Menu Makanan dibuat dengan user interface yang cukup mudah dalam pengunaan. Dalam operasionalnya data jumlah pasien teritegrasi dengan SIRS dan secara otomatis akan diinput oleh sistem sesuai dengan kelas perawatan pasien. Integrasi ini juga meminimalisir kesalahan yang dilakukan petugas terutama dalam input jumlah pasien. Sistem ini memiliki basis data standar menu, masakan, bahan makanan, serta diet pasien sesuai pedoman Peraturan Pemberian Makan Rumah Sakit. Basis data memungkinkan pengguna mengakses, membuat, memelihara dan mengontrol basis data secara praktis dan efisien.[12][13] Penggunaan basis data ini juga mengurangi subyektifitas petugas dalam menentukan jumlah masakan dan bahan makanan yang digunakan. Kualitas makanan juga turut berpengaruh terhadap kepuasan pasien.[14]

Sistem ini dapat memberikan informasi pada penggunaan jenis masakan serta bahan makanan yang paling banyak digunakan. Apakah memang bahan makanan dengan penggunaan paling banyak otomatis menggunakan biaya tertinggi. Bilamana ada bahan makanan dengan penggunaan sedikit namun berbiaya tinggi, mungkin dapat lebih diperhatikan dan diperhitungkan serta dapat dipikirkan juga alternatif penggantinya. Sistem ini juga dapat menghitung perkiraan kebutuhan bahan makanan untuk bulan bulan berikutnya berdasarkan jumlah pasien dan pemakaian bahan makanan sebelumnya.

Perbandingan sistem lama dengan sistem yang telah dikembangkan dapat dilihat pada tabel berikut:

Tabel 2. Perbandingan SI sebelum dengan sesudah dikembangkan

\begin{tabular}{|c|c|c|}
\hline Indikator & Sistem Lama & Sistem Baru \\
\hline $\begin{array}{c}\text { Tools } \\
\text { Operasional }\end{array}$ & $\begin{array}{c}\text { Microsoft Excel } \\
\text { Memerlukan beberapa petugas } \\
\text { dan } \mathrm{PC} \text { dalam pengolahan data. }\end{array}$ & $\begin{array}{l}\text { PHP MySQL } \\
\text { Hanya memerlukan } 1 \mathrm{PC} \text { dalam } \\
\text { pengolahan data. }\end{array}$ \\
\hline $\begin{array}{l}\text { Basis Data } \\
\text { Input }\end{array}$ & $\begin{array}{l}\text { Tidak Ada } \\
\text { Berulang. Data jumlah pasien, } \\
\text { menu masakan, jenis masakan, } \\
\text { bahan makanan, diet, supplier, } \\
\text { rekap pasien }\end{array}$ & $\begin{array}{l}\text { Terstruktur Relasional } \\
\text { Sekali. Data jumlah pasien, } \\
\text { menu masakan, jenis masakan, } \\
\text { bahan makanan, diet, supplier, } \\
\text { rekap pasien }\end{array}$ \\
\hline Proses & $\begin{array}{l}\text { Manual. Proses perencanaan } \\
\text { menu \& masakan, perhitungan } \\
\text { kebutuhan BM, diet pasien, } \\
\text { pengajuan kebutuhan BM }\end{array}$ & $\begin{array}{l}\text { Otomatis. Proses perencanaan } \\
\text { menu \& masakan, perhitungan } \\
\text { kebutuhan BM, diet pasien, } \\
\text { pengajuan kebutuhan BM }\end{array}$ \\
\hline Output & $\begin{array}{l}\text { Manual. Rekap jumlah pasien per } \\
\text { hari, perencanaan menu per hari, } \\
\text { perencanaan masakan per hari, } \\
\text { perhitungan kebutuhan BM per } \\
\text { hari, form pengajuan BM, rekap } \\
\text { penerimaan BM. }\end{array}$ & $\begin{array}{l}\text { Otomatis. Form pengajuan BM, } \\
\text { laporan harian penerimaan BM. }\end{array}$ \\
\hline $\begin{array}{l}\text { Pengajuan } \\
\text { Kebutuhan } \\
\text { BM ke depan }\end{array}$ & $\begin{array}{l}\text { Melalui rekap manual harian, } \\
\text { rekap bulanan. }\end{array}$ & $\begin{array}{l}\text { Otomatis, berdasarkan rekap } \\
\text { data jumlah pasien tersimpan. }\end{array}$ \\
\hline
\end{tabular}

SI Perencanaan dan Pengadaan Menu Makanan dibuat dengan PHP MySQL. Sebelum program diaplikasikan terlebih dahulu dilakukan pengujian fungsi program dengan metode Black Box. Pengujian ini dilakukan untuk mengetahui apakah fungsi - fungsi program yang ada beserta input dan outputnya dapat berfungsi dan berjalan sesuai dengan yang diharapkan. Pengujian dilakukan pada instalasi gizi RSJS dengan menggunakan Microsoft Windows 10 dan browser Mozilla Firefox. Pengujian pada 15 tampilan SI Perencanaan dan Pengadaan Menu Makanan didapatkan hasil bahwa program ini dapat berjalan sesuai dengan harapan dan siap diaplikasikan.

Secara keseluruhan telah terjadi peningkatan kualitas informasi sebesar $24.7 \%$ dari sistem sebelumnya sebesar $72.8 \%$ meningkat menjadi 
97.5\%. Bila dalam skala likert STS dan TS dikategorikan sebagai Negatif Scale serta S dan SS sebagai positif scale, maka angka rata - rata positif scale yang lebih besar adalah menunjukkan perbaikan pada sistem.[15] Adanya peningkatan kualitas informasi juga berkaitan dengan kepuasan pengguna yang berdampak pada keberhasilan sistem tersebut.[16]

\section{Kesimpulan}

Pengembangan Sistem Informasi Perencanaan dan Pengadaan Kebutuhan Bahan Makanan terbukti dapat meningkatkan akurasi, menurunkan lama waktu kerja serta meningkatkan relevansi sehingga proses perencanaan menu dan pengadaan kebutuhan bahan makanan di Instalasi gizi RSJS dapat dilakukan dengan lebih cepat, tepat dan dinamis.

\section{Daftar Pustaka}

[1] Kementrian Kesehatan RI, Permenkes Nomor 1171/MENKES/PER/VI/2011. Indonesia, 2011.

[2] "RSJS - Bersama Menjadi Bintang," RSJ Prof Dr Soerojo Magelang, 2018. [Online]. Available: https://rsjsoerojo.co.id/sejarah-singkat/.

[Accessed: 24-May-2018].

[3] Departemen Kesehatan RI. Direktorat Gizi Masyarakat, Pedoman Pelayanan Gizi Rumah Sakit. Jakarta, 2015.

[4] S. Roberts, A. Marshall, and W. Chaboyer, "Hospital staffs' perceptions of an electronic program to engage patients in nutrition care at the bedside: A qualitative study," BMC Med. Inform. Decis. Mak., vol. 17, no. 1, pp. 1-12, 2017.

[5] L. B. Whitten, Systems analysis and design methods, 7th ed. Mcgraw-Hill, 2005.

[6] Jogiyanto, Analisis dan Desain Sistem Informasi : Pendekatan Terstruktur Teori Dan Praktek Aplikasi Bisnis. Yogyakarta: Penerbit Andi, 2005.

[7] J. L. Whitten et al., System Analysis \& Design Methods, Seventh Ed. McGraw-Hill Irwin, 2007.

[8] Ayuliana, "Testing dan Implementasi," 2009. [Online]. Available: http://rifiana.staff.gunadarma.ac.id/. [Accessed: 04-Jul-2019].

[9] Furqon, Statistika Terapan untuk Penelitian. Bandung: PT Remaja Rosdakarya, 2004.

[10] Sugiyono, Metode Penelitian Manajemen. Bandung: Alfabeta, 2014.

[11] M. B. Whitehorn M, Seluk Beluk Database Relasional. Jakarta: Erlangga, 2003.

[12] Nugroho, Perancangan dan Implementasi sistem Basis Data. Yogyakarta: Penerbit ANDI, 2011.

[13] A. Kadir, Konsep dan tuntunan Praktis Basis Data. Yogyakarta: Penerbit ANDI, 2011.

[14] G. Messina, R. Fenucci, F. Vencia, F. Niccolini, C. Quercioli, and N. Nante, "Patients' evaluation of hospital foodservice quality in Italy: What do patients really value?," Public Health Nutr., vol.
16, no. 4, pp. 730-737, 2013.

[15] A. Jan, Losby., Wetmore, Using Likert Scales in Evaluation Survey Work. CDC Coffee Break, 2012.

[16] A. R. Montazemi, "Factors Affecting Information Satisfaction in the Context of the Small Business Environment.," V 12(2)., MIS Quarterly, 1988, pp. 236-256. 